


CONTENTS

Beyond the Washington Consensus: an ECLAC perspectlve

José Antonio Ocampo

The Cuban economy

David Ibarra and Jorge Máttar

Education in Latin America: demand and distribution are factors that matter

Nancy Birdsall, Juan Luis Londoño and Lesley O'Connell

Determinants of inequality among urban households

Luis Felipe Jiménez $L$, and Nora Ruedi $A$.

Health management contracts in Costa Alca from a comparative perspective

Ana Sojo

A development strategy tounded on natural resource-based production clusters

Jaseph Ramos

Blg Latin American industrial companies and groups

Celso Garrido and Wilson Peres

Between political control and efflciency gains:

the evolution of agrarian property rights in Mexico

Gustavo Gordillo, Alain de Janvry and Elizabeth Sadoulet

Tariffs and the Plano Real in Brazil

Renaso Baumann, Josefina Rivero and Yohana Zavattiero 


\section{Beyond the Washington Consensus: an ECLAC perspective}

José Antonio Ocampo

Executive Secretary, ECLAC,
This paper updates and cornplements the ideas that ECLAC has been putting forward throughout the $1990 \mathrm{~s}$, beginning with the document Changing production patterns with social equity and the contributions of Fernando Fajnzylber. After a short introductory section (section I), the salient features of the present situation of the region in the macroeconomic, social and production restructuring fields are examined in section II. In the following sections, guidelines and policies are proposed in each of these areas, with proposals that emphasize the common need to make progress with a second wave of reforms which are not merely limited to greater liberalization of markets, but seek a pragmatic inter-relationship between the State and the market. Section III examines the macroeconomic challenges involved, especially ways of handling external vulnerability and the investment, saving and financing process. Key areas at the mesoeconomic level are then analysed, especially technological development, the strategic complementarities between investment decisions, and the regulation of infrastructure services (section IV). Finally, section $V$ deals with the issues of equity and social policy, especially the factors determining equity, the spaces for social policy, and the second generation reforms in this field. 


\section{I}

\section{Introduction*}

In the course of the 1990s, the international and regional economic debate has gradually been changing in terms of its content. The initial emphasis on the principles of the Washington Consensus on macroeconomic adjustment and market liberalization has been giving way to a more balanced view in which, as the chief economist of the World Bank recently noted, more instruments and broader objectives are proposed for the development process (Stiglitz, 1998). While not denying the importance of macroeconomic stability and the advantages of more open markets, improved functioning of such markets and of the public structures is increasingly seen as an important complementary means of pursuing objectives which go beyond economic growth to include equity and social cohesion, environmental sustainability and democratic development.

In line with this approach, it is argued here that after the advances made through the structural reforms in the areas of macroeconomic stability, external openness and rationalization of the State, a second wave of reforms is now called for. These reforms cannot be limited merely to greater liberalization of the markets, however, but must pragmatically seek a mutual relationship between the State and the market which will make it possible to develop such a broad agenda. In some cases, it may also be necessary to reform the reforms themselves, in order to correct gaps in the first wave of reforms which have become evident in recent years (French-Davis, forthcoming). The present article updates and complements the ideas put forward by ECLAC in the course of the 1990 s, beginning with the document Changing production patterns with social equity (ECLAC, 1990) and the seminal contributions of Fernando Fajnzylber on which it was based (see in particular Fajnzylber, 1990).

The article first makes a brief review of the features of the present situation in the region and then deals successively with the main issues of macroeconomic management, mesoeconomic management, and the distribution of the fruits of development. Unfortunately, shortage of space prevents similar consideration of other equally important aspects such as environmental sustainability, democratic development and government structures. The brevity of the article means that it is not possible to do full justice to each of the issues dealt with, but it does serve to outline the basic elements of the strategy which ECI.AC has been proposing to the countries of the region.

\section{II}

\section{An overview of the region}

The most noteworthy economic event in the 1990s in Latin America and the Caribbean is undoubtedly the renewal of growth. This has been much more evident in Latin America, where the average growth rate of

* This is a revised version of the document prepared for the seminar "Developmem models and policies: a tribute to Ansbal Pinto" organized by the Inter-American Development Bank and the Brazilian National Economic Development Bank (Rio de Janeiro, 22-23 June 1998). The author wishes to thank Oscar Altimir, Osvaldo Rosales and Osvaldo Sunkel for their comments on a previous version of this paper and also wishes to express his gratitude for the collaboration received from various ECLAC staff members, including in particular Ricardo Ffrench-Davis,
GDP between 1990 and 1998 was markedly greater than in the previous decade (3.2\% as against $1.2 \%$ in the 1980s) and speeded up in all countries except Paraguay. In the Caribbean, however, the average

Gunther Held and Stephany Griffith-Jones, who took part in the preparation of previous documents, some of whose conclusions are incorporated in part II of this article. Conversations with Oscar Altimir and Samuel Morley were extremely useful in clarifying some of the ideas in section $\mathrm{V}$, which to a large extent incorporates the findings of a previous document by the present author (Ocampo, 1998a). Finally, the author also wishes to thank Camilo Tovar for preparing the tables and figures of this article. 
FIGURE I

Latin America and the Carlbbean: GDP growth

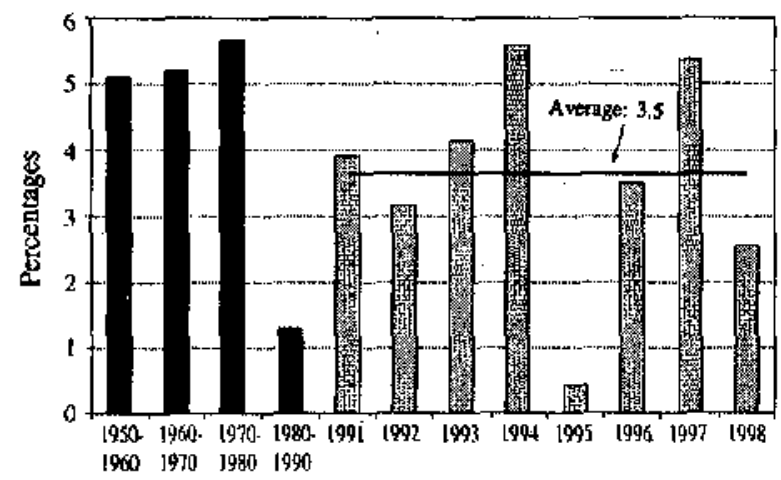

PIOURE 2

Latin America and the Carlbbean:

Groes fixed capital formalion

(\% of GDP),
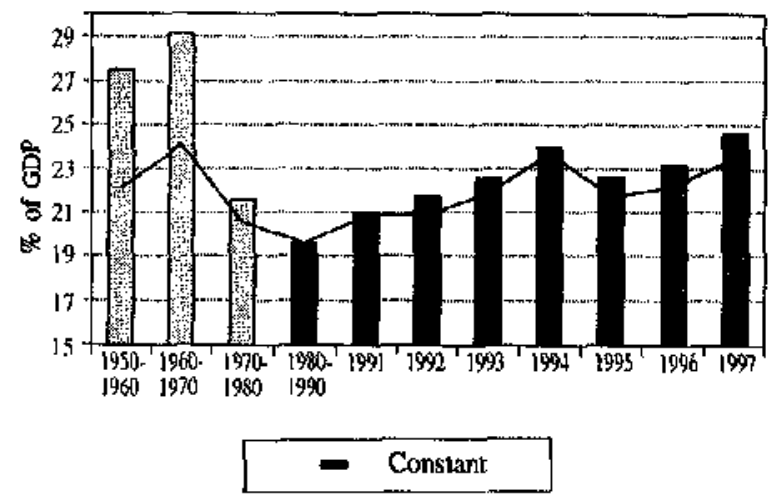

growth tate continues to be lower $(1.5 \%)$, and there are signs of slackening in a number of countries.

The average growth of the region not only continues to be slower than the level which ECLAC considers desirable for closing the gaps separating the region from the most bighly developed countries $(6 \%-7 \%$ per year) but is also lower than the average rate $(5.5 \%$ per year) registered by the region between the $1950 \mathrm{~s}$ and the $1970 \mathrm{~s}$ (figure 1), It also reflects the difficulty of recovering the levels of investment registered in the phase of fastest economic growth. Figure 2 clearly illustrates this phenomenon: the rate of investment bas recovered from $20 \%$ of GDP at the beginning of the decade to an average of $23 \%$ or $24 \%$ in recent years, but it is still well below the levels registered before the debt crisis. A feature which also gives grounds for concern is that national saving has remained at a low level, so that the financing of investment now depends to a greater extent on external saving (figure 3).
FIGURE 3

Latin America and the Caribbean:

National saving vs, grose capltal formation



FGURE 4

Latin America and the Carlbbean:

Growth and capital flows

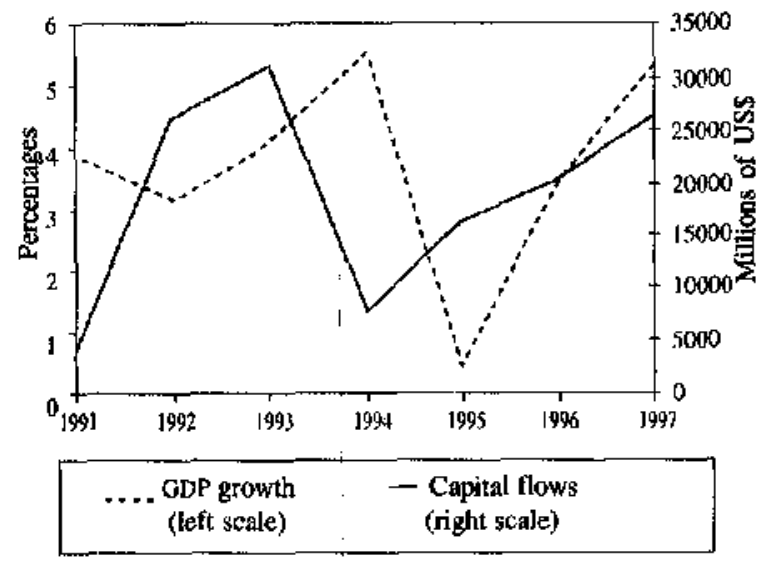

This faster growth has been accompanied by greater macroeconomic stability. The stability achieved -unprecedented in several decades- and the promptness with which the authorities take decisive action to deal with any financial imbalances which arise are clear signs of strength which have endowed the region with some strengths in the face of the upsets generated by the Asian crisis (ECLAC, 1998c). The clearest sign of macroeconomic stability is the reduction in inflation. Even after all the hyperinflationary processes had been brought under control, reducing the rate of price increases from averages of three digits at the beginning of the decade to $25.9 \%$ in 1995 , the rate was further reduced to only $10.5 \%$ in 1997 and $10.2 \%$ in 1998 . Furthermore, although problems still persist in some countries and there are clear cases of fragility, the reduction of fiscal deficits to average levels of between $1 \%$ and $2 \%$ of ODP is 
FIGURE 5

Latin America and the Carbbean:

Growth and the trade deficit

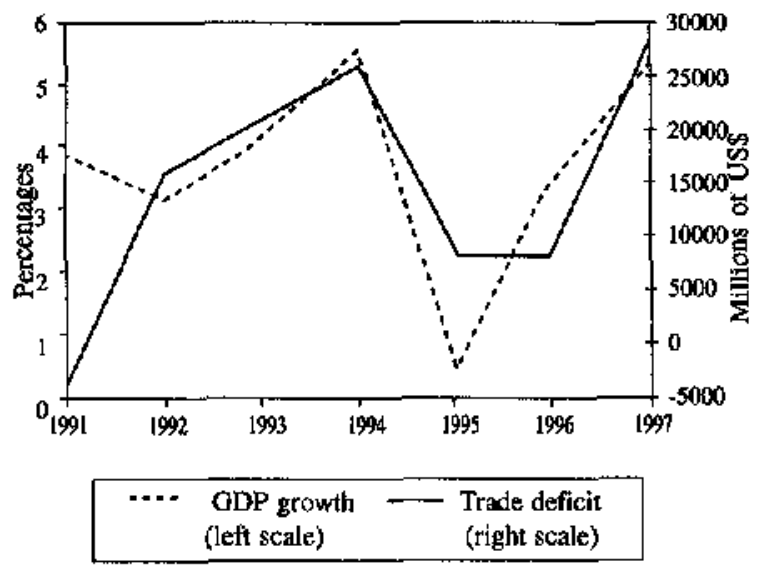

another sign of the progress made in terms of stability, as noted in the recent ECLAC report entitled The fiscal covenant (ECLAC, 1998b).

There are, however, sorme elements of concern in this field. The furst is the great sensitivity of economic growth to capital inflows (figure 4), one of whose most disturbing elements is the tendency to replace domestic saving with external saving (see section III of this paper). The second is the great sensitivity of the trade deficit to growth (figure 5), which in tum reflects the high income-elasticity of demand for imports currently displayed by the Latin American economies. In this context, the bias displayed by the recent packages of stabilization measures -emphasis on fiscal and monetary measures, yet great reluctance to use relative prices (the exchange rate) as an adjustment mechanism- seems paradoxical in view of the widespread process of real revaluation undergone by the region in the 1990s. This can bring lower rates of inflation (which is why this policy mix is more justified in countries with an important inflationary tradition), but it can lead to greater contraction than is necessary in the downward phase of the business cycle and, in general, can cause more unstable behaviour of economic activity.

On the export side, the greater dynamisn induced by the reform processes is beyond question. The volume of exports has been rising by an average of more than $10 \%$ per year since 1993, which is much faster than the average $5 \%$ growth rates of the 1980 s and early 1990s. Intra-regional trade has been particularly buoyant. Mutual trade within MERCOSUR and the Andean Community grew at the rate of $20 \%$ a year in the last five years, which puts it among the most
FIGURE 6

Latin America: Export diversiflcation

A. Latin America as a whole

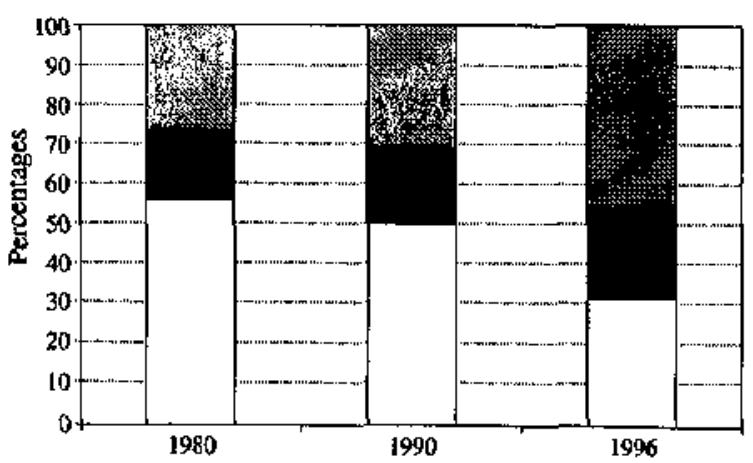

B. Latin America, excluding Mexico

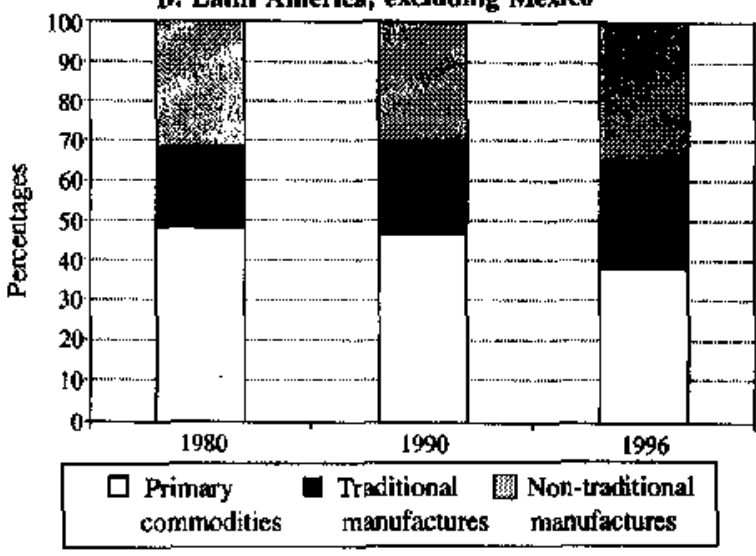

dynamic trade flows in the world. This process has coincided with a major diversification of exports: the share of primary commodities has gone down, as the relative importance of exports of manufactures has increased. This process has been particularly marked in the case of Mexico, but it is also true for the region as a whole even when that country is excluded (figure 6). Intra-regional trade has played a decisive role in this diversification. The trade boom has been based on a policy of open regionalism which has broken both with regional practices of the past (including the tendency to restrict integration agreements to non-competitive trade) and with the more orthodox views on economic integration (ECL.AC, 1994).

Finally, the trade boom has coincided with an unprecedented increase in foreign direct investment: from a little over US\$10 billion at the beginning of the decade to US $\$ 55$ billion in 1997 (ECLAC, 1998e). This growth has been based fundamentally on three processes: the privatization of State assets in the services and natural resources sectors (telecommunica- 
tions, financial services, energy and gas, etc.); the establishment or improvement of suitable conditions for the participation of private capital in the infrastructure and mining sectors, and the reorganization of transnational manufacturing firms in order to improve their international competitiveness under regional agreements (including the North American Free Trade Agreement and the Caribbean Basin Initiative) or to defend their shares in national or subregional markets. Last but not least, there bas been an unprecedented increase in intra-regional investments. The increase in direct investment has markedly improved the structure of the capital flows received by the region, undoubtedly helping to explain in part the strengths of the region in the face of recent upsets.

Although a full assessment has not yet been made of the processes of restructuring of production at the sectoral and microeconomic levels, some studies under way allow some generalizations. Although there are big differences between countries and sectors, companies have shown a surprising capacity to adapt both to the upsets of the 1980s and to the radical changes in the macroeconomic and mesoeconomic environment in the 1990 s (see, for example, Peres (ed.), 1997). Various strategies, both defensive and offensive, have been adopted for this purpose (ECLAC, 1996; Benavente, Crespi, Katz and Stumpo, 1997; Katz, 1998). The defensive strategies have been centered on: i) organizational restructuring (reduction of the number of hierarchical levels, concentration of activities in business units or centres, enhancement of the professional quality of management); ii) restructuring of production with minimal investment (neduction of production lines, greater specialization and de-yerticalization, both by importing specialized inputs and by outsourcing production activities); and iii) new marketing strategies (imports of goods and their marketing in order to complete a wide range of products and improvements in client-supplier relations). The offensive strategies included the foregoing but also added substantial in creases in new equipment and technology, acquisition of international licenes and strategic alliances with national, regional and transnational partners. The response capacity displayed shows that there has been some solid learning in previous stages of development. Trade integration has played a very important role in this process of adaptation, especially in the branches of manufacturing with the highest technological content, which makes it possible to take advantage of economies of specialization and enter into strategic intra-regional alliances to serve markets
TABLE 1

Latin America and the Carlbbean (selected countries): Rolatlve produclivliy gap compared with United States industry

\begin{tabular}{lllll}
\hline & 1970 & 1980 & 1994 & 1997 \\
\hline Argentina & 0.42 & 0.41 & 0.55 & 0.67 \\
& 0.28 & 0.26 & 0.29 & 0.37 \\
Chile & 0.25 & 0.24 & 0.23 & $0.20^{\mathrm{a}}$ \\
Colombia & 0.29 & 0.25 & 0.37 & $\mathbf{0 . 3 4}$ \\
Costa Rica & & & 0.15 & $0.14^{\mathrm{b}}$ \\
Jamaica & 0.26 & 0.16 & 0.16 & $0.13^{\mathrm{b}}$ \\
Mexico & 0.32 & 0.30 & 0.44 & $0.38^{\mathrm{c}}$ \\
Peru & 0.33 & 0.25 & 0.16 & 0.15 \\
Uruguay & 0.35 & 0.22 & 0.20 & $0.22^{\mathrm{a}}$ \\
\hline
\end{tabular}

Source: Katz (1998).

a $1995 . \quad$ b 1992, c 1994

which to other partners in the alliance know better. The adaptation of the larger enterprises has generally been less traumatic than that of the small and medium-sized firms, but even the former have lost ground to transnationals.

Generally speaking, however, there continues to be a substantial technological gap between manufacturing in the region and the best international practices (table 1). Some countries (especially Argentina, Brazil, Colombia and Mexico) are narrowing this gap: a process which began in almost all these cases in the 1980 s and which, in two countries (Colombia and Mexico), was interrupted in the present decade. A very large number of enterprises have applied defensive strategies of administrative reorganization and rationalization of their production processes, but the number which have moved on to offensive strategies, making heavy investments in equipment and technology and thus coming closer to the international technological frontier, is much smaller. In the cases where companies have expanded, there has been a tendency to increase employment, although with a much higher capital-labour ratio than in the past and with technologies making heavy use of computerization. In the case of the firms which have applied exclusively defensive strategies, the increase in productivity has been accompanied by a contraction in levels of employment, so that industrial employment has gone down markedly in almost all the countries of the region. The decline in the cost of capital goods which accompanied the recovery of the 1990 s referred to earlier has also furthered this process.

Although in one group of countries the agricultural sector has recovered growth rates similar to or higher than those of the $1970 \mathrm{~s}$, this has not occurred 
in the region as a whole. Furthermore, in many countries there is a disturbing weakening of the institutions for the development and transfer of agricultural technology, and the smaller producers have been affected by the disappearance or serious problems of the bodies which previously gave them support, without these bodies having been replaced by others of equal or greater effectiveness (Ocampo, 1998b).

The existing studies indicate that the population under the poverty line increased markedly in the 1980s. In the 1990s the situation has improved in most countries of the region, but even so, with few exceptions, the percentage of poor households is higher than before the debt crisis. In 1980, 35\% of all Latin American households were in a state of poverty, and by 1990 that proportion had risen to $41 \%$, but the level still stood at 39\% in 1994 (unfortunately, there are no similar estimates for the Caribbean or more recent global calculations for Latin America as a whole).' The 1980s was also a period of deterioration in terms of income distribution. Expectations that the renewal of economic growth would reverse that trend have not materialized, and indeed there has been a further deterioration in some countries, so that the levels of inequality are now greater than the already high levels which existed before the debt crisis (ECLAC, 1997; IDB, 1997; Morley, 1995).

In the 1990 s, there are two particularly disturbing tendencies in the labour market which are generating additional pressures in the direction of greater inequality. The first of them is the growing disparity between the wages of the highly skilled workers and those who have lower levels of skills (ECLAC, 1997). This gap has increased in almost all the countries of Latin America during the first half of the 1990s (figure 7). The second tendency is the low level of generation of formal employment and the consequent deterioration in the quality of jobs. According to estimales by the no (1997), a little over 8 out of every 10 jobs created in the 1990s correspond to low-quality jobs in the informal sector. Although the informal sector continues to be the main

\footnotetext{
I Because of the reduction in poverty in Brazil as a result of the successful application of the Plano Real and the subsequent readjustment in minimum wages, the global poverty indicator has almost certainly continued to go down in recent years. The reduction in poyerty in a broad group of countries of the region in the 1990 s is also noted by Morley (1997), on the basis of the results of a comparative study organized by UNDP, IDB and ECLAC.
}

FIGURE T

Latin Amerlca: Wage gap

A. Between professionals and format-sector workers

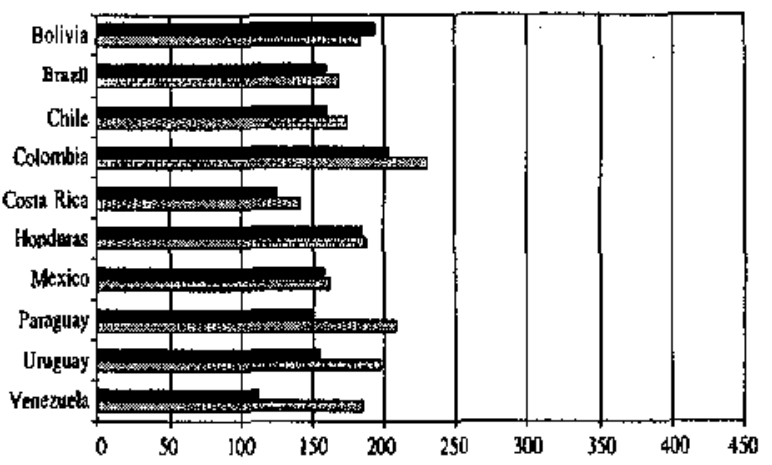

B. Between professiongls and informal-sector workers

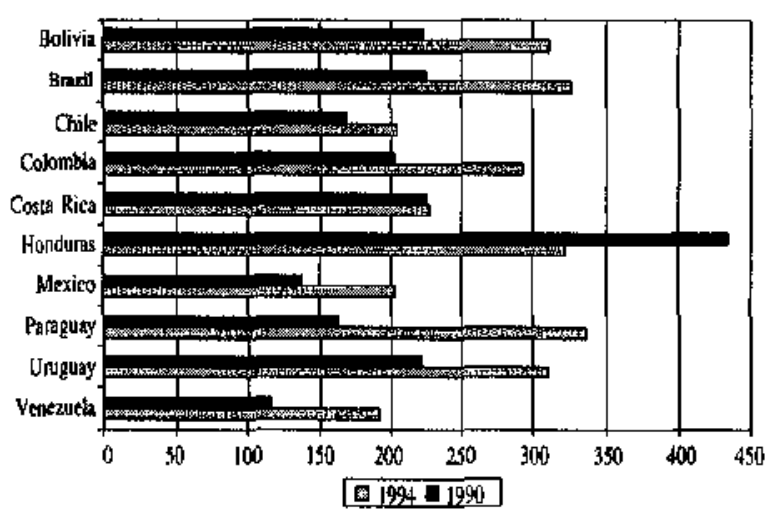

means by which the Latin American economies tackle the problem of the low rate of creation of jobs, the rate of open unemployment also increased in most of the countries of the region in the three-year period 1995-1997 (ECLAC, 1998d).

Furthermore, in the 1980s the crisis was reflected in a marked reduction in public social expenditure, both on a per capita basis and as a proportion of GDP. In the 1990s, such expenditure has recovered the levels registered before the debt crisis in Latin America, but not in the Caribbean. This recovery has been uneven in the different countries, however, and has been concentrated in types of expenditure which, according to the existing studies, have the least favourable impact on distribution (e.g., expenditure on social security). Per capita expenditure on education, however, only recovered its pre-crisis level in the mid-1990s (ECLAC, 1998b, chapter VI). 


\section{III}

\section{The macroeconomic challenges}

The recovery of high levels of macroeconomic stability, the positive view taken of the opportunities offered by open regionalism in the present context of globalization, and the search for more effective and efficient State structures are achievements of the economic restructuring process which has taken place in Latin America and the Caribbean in recent decades. As we have seen, however, there are still two disturbing elements in the macroeconomic area: the high sensitivity of growth to external capital flows and the insufficient recovery of investment levels.

\section{Dealing with external vulnerability}

In the 1990s, the Asian crisis came on top of the 1994-1995 "tequila effect" and the crisis in the European monetary system in 1992-1993, as well, of course, as the Latin American debt crisis in the previous decade. The instability characteristic of international capital flows, which has shown itself in this way in recent decades, is inherent in the functioning of such flows, as shown by economic history ${ }^{2}$ and the extensive literature on market flaws associated with information problems. As a result, the market has gone through a succession of waves of excessive expansion and financial panic, indicating that it tends first all to grow and then to contract more than is called for by fundamental economic factors. During the recent crises, other phenomena have become increasingly evident: the shortcomings in macroeconomic coordination among the nations which are most influential in the markets and the absence of suitable international institutions to manage a sophisticated but unstable financial market.

Thus, there is no international institution which helps to prevent the development of unsustainable financial booms, and the International Monetary Fund has only a limited capacity to handle the subsequent crises. The Bank for International Settlements has made some progress in the formulation of rules on bank prudential regulation and supervision, but they

\footnotetext{
${ }^{2}$ For a Latin American view, see the classic stody by Bacha and Díaz-Alejandro (1982).
}

have only been implemented to a limited extent so far. The risk grading agencies, for their part, which should be playing a role in this area, tend to accentuate rather than smooth financial cycles, as a recent study by the OECD Development Centre shows (Larraín, Reisen and von Maltzan, 1997).

This indicates that the present time would be a good opportunity for rethinking the international financial order but not a good time for considering further liberalization of that market: an issue which is currently under discussion in connection with the idea of the changing the statutes of the IMF to give it mandates with regard to the convertibility of the capital account. In this field, recent experience indicates two things. First, our attention should be centered on managing booms, not crises, since the latter are in many respects the result of booms which have not been properly managed. This is an essential point, since to some extent the existing institutions, especially the IMF, have been designed solely to handle crises, whereas we lack suitable instruments to warn us about the generation of unsustainable booms or, even better, prevent them. Secondly, the absence of a suitable regulatory framework at the international level justifies the adoption of national measures aimed precisely at controlling booms which the authorities consider to be unsustainable, especially the systems of compulsory reserve requirements on external liabilities which Colombia and Chile have been using successfully. The design of suitable domestic mechanisms for handling the volatility of external financial flows has in fact been one of the central issues studied by ECLAC in recent years (see, for example, ECLAC, 1998a, part 3 and Ffrench-Davis and Reisen (eds.), 1998).

The design of these measures should be based on the development of suitable policy instruments and institutions for handling booms or -which amounts to the same thing-for forestalling crises. In reality, the excessive attention given to crisis management overlooks a fact which ought to be self-evident: the leeway for action open to the authorities is greater in booms than in crises. Once a crisis breaks out, the authorities have no option but to take the necessary 
measures to restore confidence, which means in practice the adoption of procyclical measures. A boom marked by excessive expansion of public and private expenditure inevitably gives way to an adjustment whose severity depends on the excessiveness of the previous expenditure. Thus, an unsustainable increase in public expenditure based on windfall tax revenue and transitory access to external credit gives rise to a severe subsequent adjustment. Excessive private sector indebtedness, based on underestimation of the risks of such indebtedness, gives rise to a subsequent severe contraction in credit which, in the context of lower growth rates and higher real interest rates typical of adjustment phases, can lead to portfolio losses equivalent to high proportions of GDP, as is shown by a wide range of bank crises inside and outside the region. Overvaluation of the currency based on windfall capital inflows or transitory high prices of export products gives rise to heavy pressure on the exchange rate or interest rates once those transitory phenomena disappear.

Thus, the basic challenge for handling the external vulnerability of the economies of the region is to design suitable instruments for managing boom periods, that is to say, for forestalling crises. Some such instruments have been extensively highlighted, especially those connected with the establishment of strong prudential regulation of the domestic financial systems, including both suitable capital requirements for the financial intermediaries and systems of prudential regulation and supervision designed to prevent them from assuming unmanageable risks in boom periods. One of the corollaries of the foregoing analysis is that, when the vulnerability is greater than that which is characteristic of the more industrialized nations, the capital requirements of financial intermediaries should be stricter than those proposed by the Basle Committee of the Bank for International Settlements. There should also be strict prudential supervision of short-term external credits, particularly those intermediated by the domestic financial system. Special caution should also be adopted with respect to the use of assets whose prices are of an excessively cyclical nature as collateral for debts. For this reason, in periods of inflated asset prices, it is appropriate to make the requirements with respect to the use of such collateral more severe. Naturally, as the recent controversies on the Asian crisis also show, the authorities must give clear signals that they will in no circumstances take any action to save the assets of the owners of financial institutions (and act appropriately if a crisis does break out), thus avoiding "moral hazard" problems and demanding transparency in corporate finances in order to prevent additional financial risks.

In the foreign exchange area, the market has repeatedly rewarded a good extemal debt structure; hence, efforts to improve the maturity profile of public and private external liabilities play an essential role. In the case of public sector indebtedness, direct control should be exerted over the liabilities of all public entities, even those which are autonomous or quasi-autonomous. In the case of private indebtedness, as already noted, a system of compulsory reserve requirements (or taxes) on foreign currency liabilities is desirable. Such a system helps to improve the debt profile and, at least according to some studies, also tends to reduce (at least temporarily) the magnitude of flows during boom periods, thus playing the additional role of moderating the exchange rate and monetary pressures generated during such periods. The system designed by Argentina -establishing high liquidity tequirements for financial institutions as a function of their short-term liabilitiescan play a similar role. Within certain limits, the sterilization of the monetary effects of the increases in international reserves generated by capital inflows has also proved to be useful for preventing such inflows from giving rise to an excessive increase in domestic credit. Finally, managed exchange rate flexibility can also be useful. For this purpose, however, it is necessary to allow such flexibility to operate in both directions, avoiding the bias toward revaluation observed in many countries of the region throughout the 1990s.

Handling external vulnerability also requires the design of suitable fiscal instruments. These should include, primarily, institutional mechanisms to sterilize transitory fiscal revenues. The partial experience built up in the operation of fiscal stabilization funds associated with basic commodity exports should be extended to the management of transitory tax revenues. This means that fiscal targets should not be established as a function of the eurrent budget deficit, but of some measure of the structural deficit, as is done in the member countries of the Organization for Economic Cooperation and Development (OBCD). Indeed, many countries could opt to fully or partly offset short-term private expenditure cycles through movements in the opposite direction by public expenditure or income, thus allowing public indebtedness to compensate for trends in private indebtedness. A sound fiscal situation, both in terms of flows (surplus 
or deficit) and stocks (indebtedness) is essential, together with the maintenance of sound domestic financial systems, to obtain the degree of freedom needed to handle unfavourable extemal disturbances.

\section{Investment, saving and finance}

The causal relations between saving, investment and growth $^{3}$ operate in many different directions, giving rise to virtuous (or vicious) circles: a high level of investment generates more growth, which, in turn, increases saving and facilitates the financing of higher levels of investment. The empirical evidence tends to back up the Keynesian lines of causality, however, establishing that higher levels of saving are an effect rather than a cause of faster economic growth, and that it is the latter, through the accelerator, which induces higher levels of investment. This indicates that "autonomous" improvements (or deterioration) in the growth rate tend to reproduce themselves, through their positive effects on saving and investment.

On the other hand, high rates of investment are invariably associated with high rates of domestic saving. This association is due fundamentally to the limits which exist on the sustainability of high current account deficits (external saving). There is also ample evidence of substitution of domestic saving by external saving (figure 8), which strengthens the aforementioned linkage and indicates that a substantial part of the variations in the latter are reflected in higher or lower levels of public or private consumption. ${ }^{4}$ Furthermore, greater domestic saving is essential to cope with episodes of high inflows of capital, by accumulating international reserves in order to sterilize the expansionary effect of such capital and maintain a stable macroeconomic environment.

High levels of domestic saving are related, in turn, with high rates of public and entrepreneurial saving. The importance of the latter, in the form of undistributed profits and reserves for depreciation, was a striking feature of the Asian countries during their phase of rapid growth, and it has also been a feature of the recent experience of Chile. This indi-

${ }^{3}$ Among many recent contributions to the debate on the mutual relations between these variables, see Heid and Uthoff (1995), ECLAC (1996), Sctmidt-Hebeel, Serven and Solimano (1996), Uuhoff and Tikelman (1998) and Gavin, Hausmann and Talvi (1997).

${ }^{4}$ Half, according to estimates by ECLAC (1996) and Uthoff and Titelman (1997).
FIGURE 8

Lat|n America: Domestic saving and external soving

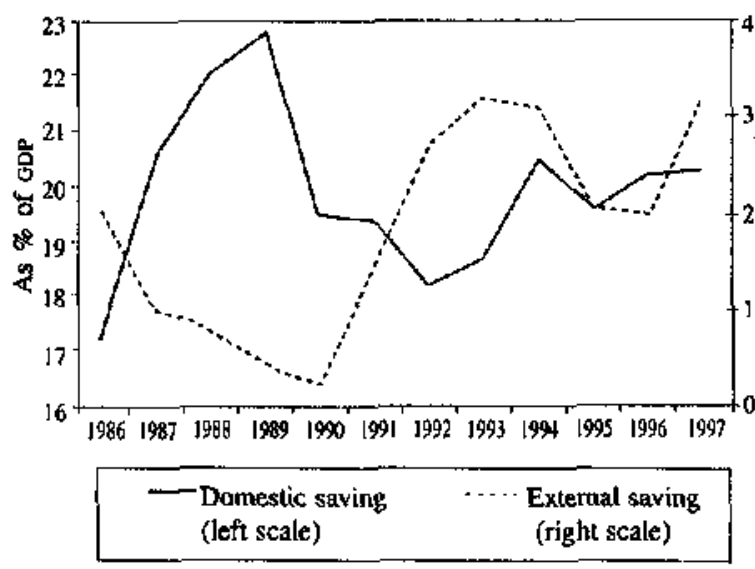

cates that the key to rapid growth is a strong link between the investment and profits of enterprises, as noted in some recent studies (for example, Akyüz and Gore, 1994), The incentives to retain profits implicit in the tax system seem to have been one of the most important elements in the recent high business saving rate in Chile. ${ }^{5}$ On the other hand, there is no solid evidence in Latin America (or even in general) which confirms the positive effects of high interest rates on saving. This indicates essentially that the substitution effects on which the positive relation between these two variables depends are offset by the income effects of the higher interest rates, which tend to increase consumption. At all events, interest rates play an important role in financial intermediation, in the allocation of resources generated through it, and in the regulation of capital flows. Household saving is much more sensitive to forced saving mechanisms, especially those associated with the social security system, but with other types too (for example, prior saving requirements for obtaining housing loans, the requirement that part of a worker's wages must be saved in severance payment funds, etc.). It is worth noting that the importance of public saving referred to at the beginning of this paragraph also establishes an important connection between saving and taxation. Although a reduction in taxation can induce higher private saving (and there is thus

\footnotetext{
${ }^{5}$ High incentives of this type also give rise to unfavourable eftects, however, which have not been absent in Chile. In particular, they facilitate the concentration of property. They also gemerate incentives for the tax evasion practices which are a natural feature of any system of taxes on capital income, such as presenting private consumption expenditure of the owners of enterprises as intermediate expenditures of the latter.
} 
some substitution of public saving by private saving), it will generally tend to be reflected, through its effects on the public accounts, in lower overall levels of national saving. In other words, taxation operates as a forced saving mechanism. ${ }^{6}$

In this context, the great expectations aroused by the transformation of social security systems from unfunded systems into systems based on individual capitalization are only partially valid. The most important effect of these reforms is that on the budget deficit, as they make it possible to reduce or eliminate the dissavings which have tended to accumulate with the unfunded systems. The new systems can also make an important contribution to the supply of longterm financial resources, although the actual channeling of these into productive activities depends on the development of suitable institutional mechanisms. The gross contribution to saving made by these systems tends to be only small, however a hittle over 3\% of GDP during the 1990s in the Chilean case) and their net effects depend on whether or not the forced savings generated by the social security system are offset by smaller voluntary saving. In the case of Chile, this latter requirement has not been fulfilled, since the greater social security saving seems to have been substituted by voluntary personal dissaving, facilitated by the ample availability of consumer goods and credit nesulting from the trade and financial liberalization. Furthermore, the fiscal cost of these reform processes is high and must be taken duly into account before embarking on them (ECLAC, 1998b, chapter VII).

The irreversible nature of investment decisions, for its part, means that this variable is sensitive to the existence of stable rules and macroeconomic environments. Measures designed to reduce macroeconomic volatility thus have positive effects on it, as also do complementary public investments, especially in infrastructure, and the availability of long-term external or domestic credit. Other important determinants are the relative prices of capital goods (which in many countries are closely associated with the real exchange rate) and, in countries with more highly developed stock markets, stock prices. Specific fiscal incentives, such as those which seek to promote investment in activities of high technological content, can also have favourable effects, but incentives which encourage investment in more general terms can prove costly in relation to their possible benefits.

6 Assuming, of course, that the higher taxation is not reflected in excessive public consumption expenditure.
The efficiency with which the financial market channels savings into investment is also an essential factor in the development process. Important requirements for this are the creation of suitable institutions and instruments, with different profit, risk and liquidity profiles, the provision of services with low intermediation costs, and prudential regulation and supervision. The public sector has a fundamental role to play in ensuring that all these conditions are fulfilled. We have already referred to the question of prudential regulation, in which respect substantial progress has been made in many Latin American countries. The high cost of financial services almost everywhere in the region indicates that there is ample room for the promotion of more competitive practices and for reducing certain macroeconomic uncertainties which are reflected in high intermediation spreads.

We will concentrate our attention, however, on the first of these instruments. The two fundamental tasks that the public authorities must face in this area are to ensure that small enterprises and poor families have access to credit, and to promote the availability of long-term funds to finance investment. Lines of credit through "second-tier" banks, subsidies for demand and/or transaction costs, and the design of guarantee funds or insurance mechanisms are the basic means of ensuring adequate coverage of financial services for small enterprises and poor urban and rural households. In spite of the progress made in some countries, this coverage is still very precarious.

The tendency of savers and creditors to reduce their risks by concentrating their operations on shortterm and fixed-income transactions also calls for an active role by the public sector in this field. The most important mechanisms for this purpose are the creation of new institutions or instruments (pension funds; other institutional investors, including overseas funds; new instruments to facilitate the financing of housing and private infrastructure; guarantee funds or credit insurance, etc.); the design of suitable regulatory frameworks and systems of incentives, and the supply of financial services by public or mixed development banks or venture capital funds. ${ }^{7}$ In this case,

\footnotetext{
7 The channaling of all or part of the stock of privalized enterprises through the stock exchanges and leadership by the government in the issue of longer-lerm bonds are also important elements, as is shown by the experience of various couniries of the region. It is also important to facilitate the issue of bonds or shares abroad, even though in this case there is no direct action to promole domestic financial intermediation.
} 
as in the provision of services for small economic agents, almost all the countries have largely maintained some public public sector institutions. Indeed, this may be the best solution, provided that rules are established which ensure the professionalism of their activities and efforts are made to avoid political interference and, above all, the temptation to turn such institutions into mechanisms for channeling subsidies, which led to their downfall in the past. However, progress in this direction, especially in the case of the capital market, is limited by a structural feature: the predominance of primarily family firms, which is of course greater in the smaller economies. This is a central factor in the design of regulatory and market promotion measures (for example, those affecting the use of resources from pension funds). In the absence of a broad supply of stocks, development banks can do much to help channel those resources into investments. Finally, although Latin American firms are making increasing use of the international market (stock issues on the New York Stock Exchange, in particular), there do not seem to be any signs of the development of regional stock markets. This could be one of the priority areas for public action in the future.
These considerations suggest the need for both a wide range of measures to improve saving and investment levels and the channels which link those two variables, and also some recommendations for caution in various areas (the foreseeable effects of the social security reforms, the impact of reductions in tax rates, or increases in interest rates on savings). One of the most interesting conclusions is that "autonomous" shifts in economic growth -that is to say, movements which are independent of the factors determining the saving and investment process - can give rise to virtuous (or vicious) circles which are reproduced through their effects on saving and investment. The various schools of thought on the determinants of economic growth identify three main channels for this. ${ }^{8}$ The first is to increase human capital: its effects are slow in coming, but its great virtue is the complementation which it establishes between growth and equity. The second is to speed up technological change. The thixd is to take advantage of the strategic complementarities of investment decisions. The last two can also have a positive influence on growth and equity. Human capital is dealt with in section $\mathrm{V}$ of this paper, while the other two types of channels belong to the mesoeconomic area and will be dealt with in the following section.

\section{IV}

\section{Key mesoeconomic areas}

The functioning of markets, their relation with the development of institutions, and the way both of these factors affect microeconomic behaviour have been among the central issues in ECLAC's proposals in recent years. Just as a good macroeconomy is needed to reduce or eliminate basic uncertainties affecting the functioning of markets, the way markets operate affects, in its turn, macroeconomic behaviour. In the ECLAC proposals, a good macroeconomy depends on a good mesoeconomy. The importance we have assigned to the functioning and regulation of the financial and foreign exchange markets in the preceding section bears witness to this assertion. The fundamental role played by the factors referred to at the end of the preceding section on economic growth is another important point.

The key issues at the mesoeconomic level are non-existent or incomplete markets and imperfections in established markets, as well as the close rela- tion between the functioning of markets and the formal and informal institutions within which they operate (the formal institutions being understood as the formal public regulation organs and the informal institutions as the customs, standards and patterns of behaviour of agents). The key issues are invariably connected with market failures, both those described in the traditional literature on imperfect competition -economies of scale, externalities and public goods- and the problems of information which have been emphasized in the economic literature in recent decades. Obviously, the possibility of correcting such flaws through public action also depends on the correction

${ }^{8}$ There are, of course, others connected with the legal atd sociopolitical context. See, for example, Barro and Sala-i-Martin (1995) and Barro (1997). 
of the no less important government failures, which include the application of rationales which are neither economic nor social (bureaucratic or clientele-based) to the functioning of institutions, problems of representation (principal-agent), the reflection of the dominant economic interests in the actions of institutions (i.e., political economy issues), the opportunities for rent-seeking opened up by State intervention, and the problems of information which also affect government actions.

The pursuit of a suitable balance between the market and the State is therefore an inherent feature of a good mesoeconomy. Obviously, such a balance will necessarily be modified by the fundamental political decisions of each society. In the present stage of development of the countries of the region, this means that special efforts should be made to create and re-invent institutions, since many of the existing institutions are profoundly affected by patterns of behaviour inherited from the past or are suffering from the deterioration undergone in the course of a long period of economic adjustment. This is true not only of public institutions affected by bureaucratic processes or corporative and clientele-based rationales but also of private institutions, such as producers' associations and trade unions which have not managed to adapt completely to the changes in their environment. The problem is not solved by the mere elimination of institutions that no longer work, as is implicit in many policy proposals. In reality, experience has shown that the worst of all "institutions" is the lack of suitable institutions for dealing with the problems which we will analyse in this section. For example. one of the lessons painfully learned in many coun tries of the region (and, even more so, in transition economies) is that the absence of suitable State regulations can tum privatization processes into massive transfers of wealth and income, without achieving efficiency objectives.

Although the spheres of action at the mesoeconomic level are very wide, we will concentrate our attention on three of them: technological develop ment, strategic complementation between investment decisions, and the regulation of infrastructure services. These issues, together with the functioning of financial markets, to which we already referred in section III, and those relating to environmental regulations (which will not be dealt with in this paper), are the key mesoeconomic areas.

\section{Technological development}

The problems raised by technological development are intimately related with the "tacit" nature of technical knowledge, i.e., the fact that it cannot be completely formalized (Katz, 1984; Katz and Kosacoff, 1998). This means that there is no perfectly codified manual ("blueprint") which can be bought in the marketplace, and that the acquisition of such knowledge is therefore necessarily associated with a learning process. This learning is also closely linked with practical experience in production activities, that is to say, it necessarily involves leaming by doing. The mastery of a particular type of technology depends on gaining experience in its use, but in addition experience makes it possible to create new technologies and to make innovations on existing ones. Indeed, technologies generally need to be adapted in order to apply them in new production contexts. This is particularly true in the case of disembodied technologies (including management and marketing techniques), but it is also true of the technologies incorporated in equipment or in special inputs (a new plant variety, for example).

Consequently, technical know-how is both a precondition and a result of the production process. At the individual and organizational level, it gives rise to a process of maturing as experience is accumulated, existing activities are expanded, and new ones are undertaken. This process of maturing thus generates individual and organizational forms of human capital. In both cases, learning is linked to the education of the persons involved, giving rise to complementation between technological and educational human capital. Moreover, this capital does not become a form of fixed property: knowledge can be taught or transmitted, the persons who have learned it can move from one organization to another, and obviously, when it is incorporated in equipment or inputs, it can be acquired. This gives rise to different types of externalities which transform both technological and educational capital into a form of social capital which we could term "knowledge capital". The accumulation of this capital is gneatly facilitated when there are suitable institutions - "innovation systems"- which support its development and generate dynamic interactions between the educational system, technological research centres and the enterprises themselves and which make it possible to take full advantage of the economies of scale of research and the externalities - characteristic of technological know-how 
(ECLAC, 1990 and 1996). These institutions are therefore a central element of "knowledge capital".

Due to the very close relation between technical know-how and production experience, there are strong links of interdependence between the use and the generation of technology. Thus, the adaptation of technology can give rise to local innovations, and accumulated production experience can result in more extensive innovations. However, advances in terms of innovation are linked with deliberate efforts to generate new processes or new products or use new inputs, that is to say, with explicit investment efforts. The specific rents obtained by the innovative enterprise are in the nature of monopoly rents and represent the great incentive for such investment, which is further increased by laws providing for its legal protection. In competitive, technologically dynamic contexts, however, investment in technology becomes an essential requirement for the very survival of the companies operating in that market.

Investments in this field involve fixed costs, associated with different types of indivisibilities, and the returns that can be expected from them are uncertain. Even imitation involves fixed costs, because of the need to acquire information, the incomplete nature of the latter, and the costs of patents and other forms of protection of intellectual property rights. For this reason, access to technology is more limited for small enterprises, and over time these tend to accumulate dynamic competitive disadvantages associated with their lower level of learning by doing. In this context, at any given time the production sectors include enterprises with very different levels of technical knowledge, so that the neoclassical concept of the "representative firm" makes little sense. This intemal differentiation of the sectors of production is of course essential for understanding the processes of reorganization resulting from competitive shocks, such as those due to the opening up of economies, or from contractionary setbacks.

The foregoing considerations have far-reaching implications for public policies. They mean, first of all, that technological processes are marked by the predominance of dynamic economies of scale, within which comparative advantages are created as a result of production experience. They also mean that the loss of production experience can have cumulative effects over time which finally destroy or considerably hold back technological know-how. Although competitive pressure has the virtue of doing away with complacent attitudes by firms and obliges them to keep up-to-date in their know-how, ${ }^{\text {iO }}$ it can also have the opposite effect: in particular, if it leads to a decline in the output of a company (or even a whole sector) it can give rise to cumulative effects on the company's competitiveness and prevent it from investing sufficiently in its technological adaptation. The predominance of defensive over offensive strategies during the processes of production restructuring in Latin America and the Caribbean (see section II of this paper) clearly shows that the introduction of more competition does not always set in motion the forms of technological adaptation which have the greatest potential for the generation of comparative advantages ("systemic competitiveness", to use the term coined by Fernando Fajnzylber and extensively used by ECLAC over the last decade). All this explains why there is not a clear association between neutrality of incentives and technological change."

These factors justify State intervention in the creation, adaptation and dissemination of technology. This is also one of the few areas where State subsidies are explicitly accepted by the World Trade Organization (within certain limits) and are therefore consistent with the present context of globalization. The protection of infant sectors of production or those which are in a stage of intensive learning ${ }_{+}{ }^{12}$ as well as the promotion of new export sectors with similar features, are the alternatives to this, but their efficient application requires clear time limits on such protection or promotion and a clear link between benefits and performance.

It may be noted that in the protectionist stage of Latin American and Caribbean history these requirements were not fulfilled, so that the results in terms of increased productivity were clearly less than optimal. 'This attitude was firmly rooted in some economic policy patterns which are all too well known. For these reasons, while not completely discounting the possible use of protection instruments which comply with the requirements we have posed, State ef-

\footnotetext{
${ }^{9}$ See, for example, the simple but elegant model by Krugman, 1990 , chapter 7.

10. This means that firms do maximize their profits, as they are below their production possibility curve, and competitive pressure therefore forces them to be on it.

11 There is a considerable amount of literature on this matler. See, for example, the studies collected in Helleiner (1992).

${ }_{12}$ On the basis of the arguments in question, there is also justification for the graduality of economic openness processes. However, this is now only of historical interest.
} 
forts should be aimed rather at supporting the development of innovation networks, promoting the establishment of new institutions, and allocating resources and generating incentives for channeling private resources to these activities. Among such institutions are sectoral or regional technological research or productivity centers, joint university-industry associations, technical assistance networks for small urban and rural enterprises, technology parks, venture capital funds for supporting technological activities, "enterprise brooders", incentives for innovation activities within firms or private contributions to technological institutions, etc. All these already form part of the Latin America and Caribbean scene, but their development has not yet attained the level which is to be desired (Alcorta and Peres, 1998).

\section{Strategic complementarities}

There is no idea which is more central to classical theories of economic development -or to location theory, which serves as the basis for regional and urban development theories- than the concept of complementarity between investment decisions or the linkages (forward or backward) that they generate, to use Hirschman's classic concept (1958). When this coincides with the presence of economies of scale in production, this gives rise, in modern terminology, to "strategic complementarities" which lead to processes of agglomeration (Krugman, 1995). ${ }^{13}$

Agglomeration phenomena lie at the very heart of the historical debates on economic development. Likewise, the observation that different economic structures give rise to different rates of growth through the strength or weakness of the economies of agglomeration they generate, as well as particular imbalances associated with the nature of such structures and the way those imbalances are solved, lies at the heart of structuralist theories of development. ECLAC's classic defence of industrialization was part of this tradition. In this context, the aggregate variables analysed by other growth theories may be seen as the effects rather than the causes of these structural dynamics. For example, rates of technical change may

\footnotetext{
${ }^{13}$ Transport costs (and distance-related transaction costs in general) play a rather more complex role. They can contribute to agglomeration but, if they are sufficiently high, they can give rise to the opposite phenomenon, as traditional location theory indicates.
}

be completely different in different structural dynamics, investment functions can also be affected, and a similar assertion may even be made regarding the rates of development of human capital they generate.

This is not, of course, the place to analyse the costs and benefits of the classic industrialization strategy ${ }^{14}$ but rather to examine the relevance of these strategic complementarities in the present stage of development of the region. Although the new technological revolution and globalization have eroded some of the bases for these processes of agglomeration, their most important implication is that "systemic competitiveness" (or its absence) is the result of synergies and externalities generated among the enterprises belonging to certain chains of production and the way these chains fit into the economy as a whole. This explains, for example, the importance of analysing the linkages generated by natural resourcebased production complexes (Ramos, 1998), or the way the integration processes currently under way are generating new production linkages between industrial sectors of different countries (in the automobile industry, for example). Another significant implication in the present stage of development of the region is the desirability of developing new systems of export promotion which provide incentives for joint action in the markets of destination by similar enterprises from the same region or country. This analysis also highlights the importance of promoting mechanisms which facilitate the exchange of information among enterprises in a given sectoral chain of production (especially with regard to possible investment decisions), encourage strategic alliances between enterprises, give rise to complementary investments, further the execution of regular analyses of the competitiveness of specific sectors of production in conjunction with the corresponding entrepreneurs, and encourage the development of research groups specializing in such analyses. The establishment of industrial parks is another strategy of the same type which is particularly important for modern regional and local planning.

The need to take strategic complementarities into account in the new stage of development has been emphasized by ECLAC throughout the 1990s (for example, in ECLAC, 1990, 1996 and 1998a). These pro-

\footnotetext{
${ }^{14}$ My own contributions to this debate are incorporated in the introduction to the study by Cárdenas, Ocampo and Thorp (eds.), 1998.
} 
posals mean, in particular, that the new development strategy does not eliminate the need for new types of sectoral policies (or, as is sometimes expressed in a more restrictive manner, for "industrial policies"). The experience being accumulated in the region indicates that such policies must arise from joint efforts between the public and private sectors, which demands profound changes in the public and private institutions inherited from the previous phase of development. The fundamental objective of such exercises should be to formulate joint "visions" and to reach a consensus on the way in which support mechanisms should be "tailored" to particular sectors. At the global level, these mechanisms are of an essentially horizontal nature (in such fields as technological development, technical training, export promotion, infrastructure, credit, etc.), but in order to be effective they need to be specified in greater detail (for example, by indicating the nature of the institutions which are to support the technological development of a specific sector, the collective requirements of the sector in terms of labour skills, the way in which the financial resources needed for its expansion are to be ensured, etc.).

It is obvious that, even though there might be theoretical justification for them, there are no grounds at present in the region for promoting more aggressive forms of sectoral planning like those carried out by the Asian countries in the past. It is important to note, however, that although strategic sectoral decisions are often not explicit, this does not mean that they do not exist. Economic openness was a clear, more or less explicit, strategic decision: the decision to give stronger support to the sectors making more intensive use of natural resources and eliminate inefficient industrial branches. When public resources are scarce, decisions to allocate funds to some sectors for their technological activities or for the promotion of their exports also involve strategic decisions (to promote these sectors rather than others, or to promote them more than other sectors). For this reason, rather than concealing such decisions, it is desirable to make them explicit through "joint views" agreed upon by the public and private sectors, including labour.

\section{Regulation of infrastructure services}

The growing privatization of public utilities and the opening of spaces for private participation in new infrastructure projects have generated important op- portunities (for eliminating serious cases of inefficiency in the corresponding sectors and attracting fresh capital, while allocating scarce public resources to other sectors), but they have also presented innumerable chalienges. Because of economies of scale and other types of technological difficulties (which have begun to be overcome in some cases), the infrastructure sectors are almost invariably marked by imperfect competition and even in many cases by natural monopolies (especially at the regional and tocal level, but even at the national level). Furthermore, in view of their character of non-tradeable services, in this case external competition does not play the same regulatory role as in the production of goods.

The first challenge that arises in this context is the need to establish suitable regulatory frameworks to ensure that the prices charged in these cases are close to those that would be established in a competitive situation and, in particular, that the greater efficiency which may be derived from the privatization processes or from greater competition is effectively passed on to consumers. The regulatoty problems in the transition to privatized infraestructure services are extremely complex, especially because they involve the task of creating markets and not just regulating existing ones. Furthermore, the agents are at different stages of assimilation of the new policy frameworks and are working with even more asymmetrical information than in mature markets. It is worth emphasizing the decisive importance, in this context, of establishing not only highly qualified regulatory bodies, but also superintendencies to monitor the application of their decisions and enter one of the areas most often forgotten by the old policy framework: consumer defence.

The second challenge is the proper management of public guarantees. This problem is particularly important in new infrastructure projects, where the private sector only participates if the State is willing to provide guarantees against risks that the private agents consider they cannot assume (regulatory risks and force majeure, but also risks regarding future income, liquidity, or unforeseen cost increases). The assumption of these risks by the State gives rise to considerable fiscal contingencies. For this reason, it is necessary, first of all, to design private participation schemes which minimize the granting of such guarantees, limiting the risks assumed by the State to those which cannot be insured in the market and which the private sector cannot really control. More- 
over, the risks assumed by the public sector must be suitably estimated. The corresponding calculations, even if imperfect, must be taken into account in the annual budget debate and it is even desirable that a value equivalent to the annual premium of the "insurance" granted by the State should be explicitly budgeted. This would also make it possible to compare this form of financing with options which involve larger public sector resources, such as projects financed by the public sector but privately managed. ${ }^{15}$

The problems arising in connection with regulation and the granting of guarantees bring us to a third challenge: the need to avoid rent-seeking practices which can be just as much of an aberration as in the previous public scheme, if not more so. In this respect, it is essential to adopt social control mechanisms which avoid the "capture" of the regulatory bodies by the companies they are supposed to regulate. It is also necessary to estimite and publicly discuss, in comnection with the budget debate, the practices governing the granting of guarantees and the amounts of such guarantees given by State institutions, as well as establishing clear rules which eliminate "implici" guarantees (i.e., the perception that private projects which fail will be rescued by the public sector), which can give rise to serious "moral hazand "issues.

\section{V}

\section{Equity and social policy}

\section{The challenge of equity}

The equity problems which characterize the region stem from highly unequal distributive structures, largely inherited from previons stages of development. As noted in a recent report by ECLAC (1998d), they reflect a whole set of factors relating to education, employment, wealth and demographic structures. The large inequality in the number of years of schooling of employed persons has been the factor given most emphasis in recent debates. The lack of equity is also related to the unequal distribution of wealth, which is even more concentrated than educational opportunities (see, in this respect, Bindsall and Londoño, 1997). Likewise, the number of employed persons per household is smaller in low-income households, and the jobs they manage to obtain are less skilled. Finally, poor families have more dependent children.

In addition, behind the national patterns there are also considerable regional disparities, so that the problems of poventy are relatively more concentrated in those regions which have the grealest difficulty in integrating into the development process. Although in the long term migration tends to promote the levelling-out of regional disparities, it can have adverse

\footnotetext{
15 With respect to these questions, see the studies included in Irwin, Kbein, Perry and Thobani (eds), 1997, and ECLAC, 1998 , chapter $\mathrm{XX}$.
}

effects for long periods of time, since it is selfetive: that is to say, it tends to take the persons with the most human capital away from backward regions. The same thing occurs with the mobility of capital, which, although it may have levelling effects in the long term, can give rise for long periods, through economies of agglomeration, to a strong attraction of capital to the most dynamic centres of development.

Following the studies by Morley (1994 and 1995), varions other studies have confirmed that poverty tends to decline with economic growth. The increase in poverty during the 1980 s and its reduction during the 1990s is in line with this pattern. Strictly speaking, however, this is only true for urban poverty, since rural poverty, and above all extreme rural poverty, behave in a much more inertial manner, typical of "hard core poverty" (Ocampo, 1998b). Moreover, the data fully confirm the deterioration in income distribution which has taken place over recent decades in a number of countries of the region. ${ }^{16}$ The analysis of this process has given rise to an active controversy involving fundamentally two alternative theories. The first of these posits the existence of an asymmetrical behaviour of the incomes of the poorest sectors in acute growth cycles like those which the Latin American economy has undergone in

\footnotetext{
${ }^{16}$ For a fuller analysis of these irends, see Altimir (1997), Benty (1998), Morley (1994 and 1995), IDB (1997) and BCL.AC (1997).
} 
recent decades: they tend to go down mone in periods of crisis than they manage to recover in boom periods. This probably reflects the loss of human capital (experience) during crisis periods and asymmetrical behaviour of the labour market (employment cuts during the crisis are not followed by similar increases in the boom periods, those who lose their jobs also lose labour connections which they never recover, etc.). The second theory holds that economic liberalization and globalization have tended to deteriorate income distribution.

One of the authors who has supported the latter view most strongly is Albert Berry. This anthor bas shown in varions studies that there is evidence in the last quarter of a century that the introduction of economic liberalization measures has been associated with often serious deterioration in income distribution (Berry, 1998). ${ }^{17}$ The comparative study by Robbins (1996) also shows that trade openness processes have tended to give rise to greater inequality in labour income distribution. The increases in the income disparities between more and less skilled workers during the 1990 s (BCLAC, 1997) and the sluggishness of job creation in the formal sector, already referred to in section II, may also help to confirm this view. This growing inequality in wages as a function of levels of skils does not seem to be confined to the region. Indeed, a recent report by UNCTAD (1997) indicates that this may be an almost universal pattern, since it has also affected a number of industrialized countries and some rapidly growing economies in the Asia-Pacific region and in particular has given rise to severe pressures on the middle classes in many countries.

There ane various possible explanations for these trends. One of the most interesting is that of Rodrik (1997), who claims that globalization accentuates the asymmetry between the factors which can cross national frontiers most easily -capital and highly skilled labour- and those which cannot do so: less skilled labour. The possibility of relocating production means that the demand for labour is more elastic in all countries, reducing the bargaining power of workers and increasing the instability of their income vis-à-vis demand disturbances. Furthermore, Berry (1998) claims that the explanation for this may be connected with the economies of scale in interna tional trade and finance, which are reflected in the

17 This autbor's information is taken frorn the canes of Argentina, Chile, Colombia, Mexico, the Dominican Republic and Uruguay, Costa Rica being an exception to this rule. bigger share of the biggest firms in each sector in these activities. These firms ane, in tum, those which make intensive use of capital and/or more skilled labour. It has also been suggested that the transfers of technology generated by trade, including technology incorporated in imported machinery and equipment. can cause developing countries in the midst of internationalization processes to adopt technologies which require highly skilled labour and were designed to moet the needs of the industrialized countries (Robbins, 1996). The production restructuring strategies of Latin American enterprises in response to the greater openness and globalization have had unfavourable effects on job creation, as already noted in previous sections.

In the case of Latin America, there may be other explanations for this phenomenon. One of them is that the liberalization process took place after a decade of weakening social expenditure. Thus, the greater demand for more skilled labour came up against an inelastic supply of such workers. Moreover, during the liberalization process no clear efforts were made to link up the demand for and supply of skills. Another explanation might be that the macroeconomic policy which has accompanied the reform process -especially the tendency towards revaluation of exchange rates and opening up of capital accounts - has given rise to growth pattems in which imports have grown more than exports, also generating a bias against the labour-intensive sectors. Macroeconomic management has also been characterized by marked "stop and go" cycles associated to capital flows, which his hindered the generation of mone stable jobs.

\section{Socid pollicy}

These considerations mean that, coming as they did on top of an already nnequal distributive structure, the debt crisis, liberalization and globalization (to which the different explanations attach different dogrees of importance) have enormously increased the challenge with regard to equity. One of the great challenges facing the region is therefore to show that the new development model is compatible with the gradual correction of the great existing social inequalities. If this objective is not attained, this could undermine the political bases of the reforms, which have been very sound so far, largely because the recovery of macroeconomic stability has been seen as a positive development by the population as a whole. Moreover -which is equally serious- social tensions 
could arise which make governance difficult and erode the bases of the political consensuses which have made it possible to strengthen democracy in the region, undoubtedly another of the great achievements of recent years. In the longer term, the sequels of inequality and poverty could undermine the bases of systemic competitiveness on which the possibilities of development within an increasingly open international context depend.

Intenational experience shows some surprising results with regard to handing the social risks that globalization has brought with it. The study by Rodrik (1997) indicates that in the past, greater openness of economies has been compensated by greater social protection of the population by the State. This has been reflected in a positive relation between the degree of openness and the size of the State. According to this author, this is true both for the OECD countries and for a broad sample of 115 countries, which would seem to indicate that the distributive tensions generated by processes of greater openness have been tackled in the past by trading economic liberalization for greater State protection through a more active social policy.

Social expenditure is undoubtedly the most important component through which the State can influence income distribution. Indeed, there is ample proof that social expenditure has a significant effect on secondary income distribution. The information available for Latin America on this matter indicates that, in absolute terms, the higher-income groups benefit more from social expenditure. As a proportion of the income of each stratum, however, the subsidies channeled through such expenditure are greater for the poorer sections of the population. This global pattern is the result of the very different distributive impacts of different types of expentiture. The degree of focusing on the poor (that is to say, the proportion of the expenditure which is channelled to the poor in retation to the proportion of the population in a state of poverty) is high in the case of expenditure on health, primary education and, to a lesser extent, secondary education. In contrast., expenditure on social security and higher education has a generally regressive tendency. Expenditure on housing is in an intermediate situation, since it benefits in particular the middle strata of the income distribution scale. These results indicate that there is plenty of room for improving income distribution through social expenditure, but also for improving its targetting, as pointed out in a recent ECLAC study. The way in which such expenditure is financed is by no means irrelevant in this connection: financing from direct taxes tends to be more progressive than financing from indirect taxes and, what is equally important, unsuitable financing which is reflected in an increase in inflation can cancel out the favourable distributive effects (ECLAC, 1998b, chapter VI).

There is therefore a good deal of room for combining economic liberalization with a mone active social policy, as indeed traditional international patterns seem to reflect. It is necessary, then, to make an effort to reorient public expenditure towards the social sector -as Latin America has already begun to do in the 1990s- and to target social expenditure and maximize its favourable distributive effects. Some countries could also possibly opt for additional expansion of social expenditure, financed from greater tax revenues. Indeed, this was the altemative chosen by the Chilean government in the early years of the present decade, without thereby adversely affecting real investment or economic growth. This is also the option followed by Colombia in the 1990s (the country of the region which has most markedly increased its social expenditure in this decade), although in this case there has been a financial shortfall making necessary a fiscal adjustment which has not been carried out in full. In these cases, the net distributive impact will depend, as we bave seen, on the nature of financing.

In the long term, greater investment in human capital also makes it possible to influence one of the structural factors of income distribution. Thus, the existing studies show that greater allocation of resources to education, which makes it possible to improve the distribution of human capital in society, can have much greater effects on income distribution than those estimated in studies on the short-term incidence on distribution (see, for example, IDB, 1997). As a cautionary note, however, it should be emphasized that there is also confirmation that a big effort in education will tend to be reflected in decreasing returns on the investment in it. Furthermore, as in a growth process the economy demands higher levels of education for the same type of job, there is a "devaluation" of education in the labour market and hence also of its capacity to generate higher income.

This is indicated by a recent report by ECLAC (1998d). This report finds that the increase in the average years of schooling registered in recent decades in Latin America (by an average of three and a half years, if the number of years of schooling of young people between 20 and 24 are compared with 
those of their parents) has not succeeded in improving the opportunities of young people from poor social strata. Thus, the report finds that only half of urban young people and a quarter of rural young people have improved their educational level compared with their parents by more than the rise in the educational demands of the labour market, so that they effectively have greater employment opportunities than their parents. This fits in with the results of surveys which indicate that only half of Latin American young people consider that they have better opportunities than their parents.

Likewise, the report in question shows that efforts to expand the coverage of education have not been reflected in a reduction in the distance separating young people of different social strata. In particular, in comparison with the educational capital of their parents, the educational achievements of young Latin Americans have not improved (or have improved only marginally) over the last 15 years. ${ }^{18} \mathrm{It}$ was also noted that young people with the same educational level and the same occupation earn between $30 \%$ and $40 \%$ more than the other young people in their age group if they come from households where the parents have higher incomes. This shows that the expansion of education in a context of social inequality does not always result in equality of opportunities. Even in Chile -where a better distribution of educational opportunities has coincided with a very dynamic economy and a positive rate of job creation, which has been reflected in a marked reduction in poverty- income distribution has nevertheless not shown any improvement so far.

For this reason, although higher levels of education and better distribution of educational opportunities are essential, they are not in themselves sufficient to improve income distribution. It is necessary to apply simultaneous policies in the areas of education, employment, distribution of wealth and population. and to direct particularly aggressive action on all these fronts towards rural areas and regions which are backward or have tended to lag behind with the changes in development patterns.

In the case of education, the reforms should be aimed at ensuring that young people receive a fuil

\footnotetext{
${ }^{18}$ At the beginning of the 1980 s, for example, the proportion of young people whose parents had between six and nine years of schooling but who themselves succeeded in obtaining a full secondary extucation was between $33 \%$ and $43 \%$ in the countries studied; in the mid-1990s, this proportion was practically unchanged, standing at between $36 \%$ and $46 \%$.
}

secondary education of suitable quality at a suitable age, and at reducing the enormous gap that still remains in all countries between educational opportunities in the cities and in nral areas. They should also be aimed at making up for the disadvantages with which children from the poorest homes begin their studies, by expanding the coverage of pre-school exlucation, keeping young people for a longer time in the school system, and dealing adequately with the problems of adolescent pregnancy, which affect the educational opportunities of both the mother and her children. As the extensive literature on this subject indicates, advances in education (and the special efforts in this direction) must also be accompanied by conscious family planning to reduce the problem of a high ratio of dependents which characterizes the poorest households.

With regard to employment, the most important efforts must be aimed at training for future employment and the development of integral support networks (management training, transfer of technology, credit, new marketing channels) for urban and rural small-scale and micro-enterprises, where the persons with the lowest incomes work. Although globalization undoubtedly requires that some labour regulations should be made more flexible, the solution of the structural employment problems in the region obviously does not lie in the radical liberalization of the labour market. Furthermore, such greater labour flexibility as is politically agreed upon in each country must be accompanied by greater social protection in other fields. In particular, there is clear evidence in the region that more active policies with regard to minimum wages (obviously, within macroeconomically sustainable limits) have been associated with bigger reductions in the size of the poor sectors in the 1990s (Morley, 1997). Systems for providing information on employment opportunities and vocational training, especially for those who have lost their jobs, still lag far behind in the region.

Finally, emphasis must be placed on the need to direct attention towards opportunities for improving the distribution of assets, such as policies designed to help small producers and social housing programmes. In this field, one of the aspects which deserves special attention is that of ways of redistributing assets which do not give rise to distortions in economic activity, such as the establishment or improvement of institutions for channeling credit to small enterprises or micro-enterprises without distort- 
ing the market, or the new agrarian reform schemes which make active use of the land market.

\section{Social policy and the second generation reforms}

The efforts to increase and target social expenditure in the region must be suppiemented with a thorough reorganization of the sector to make the supply of social services more efficient and effective. This is one of the central aspects of what have been called the "second generation" reforms, whose essential purpose is to increase the efficiency of the markets and incorporate criteria based on a microeconomic rationale in the provision of those services where this approach has previously been absent.

With regard to social services, emphasis has been placed on the introduction of elements of competition in their supply (creation of quasi-markets), with the participation of private agents and changes in the forms of State support from the traditional subsidies for the supply of such services to demand subsidies. At the same time, and in a complementary manner, efforts have been made to decentralize the provision of those services for which the State continues to responsible, to create new systems of results-oriented public management, to give the public bodies responsible for supplying services effective autonomy, and to establish participatory mechanisms for the control of public management. All the components in this reorganization, but especially the first-named, are designed to tackle the government failures which have become evident in the past in the provision of social services and which are reflected in the inefficiency and low quality of the services provided by the State.

Experience shows that while the private sector responds dynamically to the incentives given to it, such participation is subject to market failures, both of a traditional nature, related with economies of scale, and failures associated with information problems, highlighted in the more recent literature, which give rise to phenomena of imperfect competition, adverse selection and "moral hazard" (Ocampo, 1996). In economies with severe disparities in distribution, the most important problem is that of the natural attraction, generated by the market, whereby the private sector directs its supply -both in terms of quantity and, in particular, quality- to the higher income groups. This problem is not necessarily solved through a system of demand subsidies, and therefore requires that the State should design instruments to increase the supply directed to the lower income groups. As the public supply has in many cases likewise been incapable of reaching certain sectors of the population (as for example in social housing programmes), it is necessary to promote the participation of new agents, generally of a non-profit or community nature.

The above difficulties are further accentuated when the design of private participation schemes does not include clear principles of solidarity, as the private health system in Chile shows (ECLAC, 1998b, chapter VII). In this case, adverse selection -both by income levels and by the health risks associated with the age of the population covered- can be very marked. The introduction of solidarity elements does not automatically solve this problem, however. Thus, for example, the health reform in Colombia established a system in which the benefits are totally independent of the amount of the contribution, but the response of the private sector to the needs of the poorest strata has nevertheless been frustrating. The private response can also be geographically unbalanced: the response is better in large cities, but it is insufficient in small towns and the rural sector, where -because of the very low economies of scale- there may be "natural monopolies" in many services in conditions in which, moreover, their provision is not profitable.

When supply does not respond properly -in terms of quantity or quality- to the incentives generated by demand subsidies, it may be desirable to design intermediate formulas which might be called "demand-oriented supply subsidies" and which would make it possible to influence supply, including the quality of the services provided, while at the same time obtaining the traditional benefits of demand subsidies in terms of the targeting of beneficiaries. Such intermediate schemes consist of the signing of contracts with particular agents to provide services to a specific population group through a system of competitions, or the promotion of community or non-profit organizations with the explicit purpose of entrusting them with the administration of the services in question. This could also be a suitable system for promoting the creation of new services or improving the quality of existing ones (for example, raising the quality of the educational system, as is being done in Chile).

Problems of information are much more serious in the services markets than in those for goods. In particular, there are virtually insoluble asymmetries in information between those who provide 
highly specialized services and those who receive them (between doctors and patients, in particular, in the case of health, but similar phenomena are also observed in education). For this reason, the development of quasimarkets for the provision of social services requires the establishment of certain minimum schemes for the provision of information, as well as highly developed instruments for protecting users.

The reforms adopted in this context must be pragmatic and must therefore involve a substantial component of gradualism and leaming from experience. It must also be borne in mind that the new schemes of private participation are not a substitute for the public supply of services in all sectors. For this reason, efforts to improve public supply through decentralization, the autonomy of the units providing services, the introduction of criteria for the assessment of public managenent, and citizen control are undoubtedly vital elements of any reform with regard to social services.

Finally, it should be emphasized that one of the main features in the reform of social services should be the design of suitable systems of regulation, information and quality control of the services provided. This is particularly important when the specialized nature of the services does not guarantee the transparency of the information that consumers use to select their suppliers. This is a matter which is still at an incipient stage and which will require considerable efforts in the years to come.

(Original: Spanish)

\section{Bibliography}

Alcorta, L. and W. Peres (1998): Innovation systems and technological specialization in Latin America and the Caribbean, Research Policy, vol. 26, Amsterdam, North-Holland.

Altimir, O. (1997); Desigualdad, empleo “y pobreza en América Latina: efectos del ajuste y del cambio en el estilo de desarrollo, Desarrollo económico, vol. 37, No. 145, Buenos Aires, Instituto de Desarrollo Económico y Social (IDES), April-June.

Akyiu, Y. and C. Gore (1994): The Investment-Profits Nexus in East Asian Industrialization, Discussion papers, No. 91, Geneva, United Nations Conference on Trade and Development (UNCTAD).

Bacha, E. and C.F. Díaz-Alejandro (1982): International Financial Intermediation: A Long and Tropical View, Essays in International Finance, No. 147, Princeton, NJ, Princeton University, Department of Economics, International Finance Section, May.

Batro, R. J. (1997): Determinants of Economic Growth: A Cross-Country Empirical Study, Cambridge, MA, MIT Press.

Barro, R. J. and X. Sala-i-Martin (1995): Economic Growth, New York, McGraw-Hill.

Benavente, J. M., G. Crespi, J. Katz and G. Stumpo (1997); New problems and opportunities for industrial development in Latin America, Oxford Development Studies, vol. 25, International Development Centre, Oxford, U.K

Berry, A. (1998): Confronting the income distribution threat in Latin America, in A. Berry (ed.), Poverty, Economic Reform, and Income Distribution in Latin America, Boulder, CO, Lynne Rienner.

Birdsall, N. and J. L. Londoño (1997): Asset Inequatity Does Matter: Lessons from Latin America, Working Paper No. 344, Washington, D. C., WB.
Cárdenas, E., J. A. Ocampo and R. Thorp (eds.) (1998): Industrialization and the State in Latin America: The Black Legend and the Post-War Years, London, Macmillan (in the press).

ECLAC (Economic Commission for Latin America and the Caribbean) (1990): Changing Production Patterns with Social Equity, LC/G.1601-P, Santiago, Chile. United Nations publication, Sales No. E.90.II.G.6.

(1994): Open Regionalism in Latin America and the Caribbean. Economic Integration as a Contribution to Changing Production Patterns with Social Equity, LC/G.1801/Rev.1-P, Santiago, Chile. United Nations publication, Sales No. E.94.Il.G.3.

(1996): Strengthening Development. The Interplay of Macro- and Microeconomcs, LC/G.1898(SES.26/3), Santiago, Chile. United Nations publication, Sales No. E.96.II.G.2.

-(1997): The Equity Gap. Latin America, the Caribbean and the Social Summit, LC/G.1954/Rev.1-P, Santiago, Chile. United Nations publication, Sales No. E.97.II.G.11.

-(1998a): Latin America and the Caribbean: Policies to improve linkages with the global economy, LC/G.1800(SES.25/3), Santiago, Chile.

- (1998b): The Fiscal Covenant. Strengths, weaknesses, challenges, LC/G.2024, Santiago, Chile, April.

(1998c): Impact of the Asian Crisis on Latin America, LC/G.2026, Santiago, Chile.

-(1998d): Social Panorama of Latin America, 1997, LC/G.1982 P Santiago, Chile. United Nations publication, Sales No. E.98.Il.G.3

(1998e): La inversión extranjera en América Latina y el Caribe. Informe 1997, LC/G. 1985-P, Santiago, Chile. United Nations publication, Sales No. S.97.IIG.14. 
Fajnzylber, F. (1990): Industrialization in Latin America: From the "Black Box" to the "Empty Box", "Cuadernos de la CEPAL" series, No. 60, LC/G.1534/Rev.1-P, Santiago, Chile, ECLAC.

Ffrench-Davis, R. (forthcoming): Reforming the Reforms in Latin America: Macroeconomics, Trade, Finance, London, Macmillan.

Ffrench-Davis, R and H. Reisen (eds,) (1998): Flujos de capital $e$ inversión productiva. Lecciones para América Latina, Santiago, Chile, ECLAC/Organization for Economic Cooperation and Development (OECD).

Gavin, M., R. Hausmann and E. Talvi (1997); Savings behaviour in Latin America: Overview and policy issues, in R. Hausmann and $\mathrm{H}$. Reisen (eds.), Promoting Savings in Latin America, Paris, OECD/LDB.

Held, G. and A. Uthoff (1995): Indicators and Determinants of Savings for Latin America and the Caribbean, Working Papers, No. 25, Santiago, Chile, ECLAC.

Helleiner, G. K. (ed.) (1992): Trade Policy, Industrialization and Development: New Perspectives, Oxford, Clarendon Press.

Hirschman, A. O. (1958); The Strategy of Economic Development, New Haven, CT, Yale University Press.

IDB (Inter-American Development Bank) (1997): Progreso económico y social en América Latina. Informe 1997, Washington, D.C.

ILO (International Labour Organisation) (1997): Panorama laboral '97, Lima.

Irwin, T., M. Klein, G. Perry and M. Thobani (eds.) (1997): Dealing with Public Risk in Private Infra. structure, Washington, D.C., World Bank.

Katz, J. M. (1984): Domestic technological innovations and dynamic comparative advantage: Further reflections on a comparative case-study program, Journal of Development Economics, vol. 16. Nos. 1-2, Amsterdam, Elsevier Science Publishers, B.V.

(1998): Crecimiento, cambios estructurales y evolución de la productividad laboral en la industria manufacturera latinoamericana en el perlodo 1970-1996, Santiago, Chile, ECLAC, Division of Production, Productivity and Management, mimeo.

Katz, J.M. and B. Kosacoff (1998): Aprendizaje tecnológico, desarrollo institucional y la microeconomía de la sustitución de importaciones, in E. Cárdenas, J. A. Ocampo and R. Thorp (eds.), Industrialization and the State in Latin America: The Black Legend and the Post-War Years, London, Macinillan (in the press).

Krugman, P. (1990): Rethinking International Trade, Cambridge, MA, MIT Press.

-(1995): Development, Geography and Economic Theory, Cambridge, MA, MIT Press.
Larraín, G., H. Reisen and J. von Maltzan (1997): Emerging Market Risk and Sovereign Credit Ratings, Technical Papers, No. 124, Paris, OECD, April.

Morley, S. A. (1994): Poverty and Inequality in Latin America: Past Evidence, Future Prospects, Policy Essays, No. 13, Washington, D. C., Overseas Development Council (ODC).

(1995): Poverty and Inequality in Latin America: The Impact of Adjustment and Recovery in the 1980s, Baltimore, MD, Johns Hopkins University Press.

- 1997): Poverty during recovery and reform in Latin America: 1985-1995, Washington, D.C., IDB, May, mimeo.

Ocampo, J. A. (1996): Participación privada en la provisión de servicios sociales: el caso colombiano, Coyuntura social, No. 14, Santafé de Bogotá, Tercer Mundo Editores, May.

(1998a): Income distribution, poverty and social expenditure in Latin America, Cepal Review, No. 65, LC/G.2033-P, Santiago, Chile, ECLAC, August.

(1998b): Agricultura y desarrollo rural en América Latina: tendencias, estrategias, hipótesis, Santiago, Chile, ECLAC, mimeo.

Peres, W. (ed.) (1997): Politicas de competitividad industrial: América Latina y el Caribe en los años noventa, Mexico City, Siglo XXI.

Ramos, J. (1998): A development strategy founded on natural resource-based production clusters, CEPAL Review, No. 66, Santiago, Chile, ECLAC, December.

Robbins, D. (1996): Evidence on Trade and Wages in the Developing World, Technical Papers, No. 119, Paris, OECD, Development Centre.

Rodrik, D. (1997): Has Globalization Gone Too Far?, Washington, D.C., Institute for International Economics (IIE).

Schmidt-Hebbel, K., L. Servén and A. Solimano (1996): Savings, investment and growth in developing countries: An overview, in A. Solimano (ed.), Road Maps to Prosperity: Essays on Growth and Development, Ann Arbor, MI, University of Michigan Press.

Stiglitz, J. A. (1998): More instruments and broader goals: Moving toward the post-Washington Consensus, 1998 Wider Annual Lecture, Helsinki, United Nations University, World Institute for Development Economics Research.

UNCTAD (1997): Trade and Development Report 1997, Geneva.

Uthoff, A. and D. Titelman (1997): La relación entre el ahoro extemo y el ahorno nacional en contextos de liberalización financiera, in R. Ffrench-Davis and H. Reisen (eds.), Flujos de capital e inversion productiva: lecciones para America Latina, Santiago, Chiłe, ECLAC/OECD. 